\title{
Innovation to Course System of Chinese Language and Literature Major in Colleges and Universities
}

\author{
Yong Jia \\ College of Business, Xi'an International University, Xi'an, 710077, China
}

Keywords: Higher education, Chinese language and literature, Course system, Reform and innovation

\begin{abstract}
Major of Chinese language and literature is the basis for school running of arts in Chinese higher education institutions at present. At the same time, it is also of great importance for inheritance and development of Chinese culture. Therefore, Chinese education departments attach great importance to it. In the present stage, colleges and universities in various places gradually realize the importance of Chinese language and literature major in humanistic education for students. Therefore, they continuously made innovative explorations to their course systems in the new period, and expected to improve the teaching quality and lay a solid foundation for students' future development through more matched course system. In this paper, the author specially explains the thought and framework of course system for Chinese language and literature major in colleges and universities. On this basis, the author also makes an appropriate research on innovative policies, with the expectation to provide certain support and reference to innovative reform to course system in colleges and universities.
\end{abstract}

\section{Introduction}

Called by national education departments in recent years, colleges and universities in various places have positively joined in and explored for innovation to course system reform, which urges education system of colleges and universities to be more complete to some extent. At the same time, scientificity, rationality and practicability of course teaching are obviously intensified. The major of Chinese language and literature is served as a major with deep cultural deposits. With era development in these decades of years, their course systems are continuously enriched and completed. As a whole, however, no any systematic reform or innovation is made, and it also has adverse effect on improvement to teaching effect. In the new period, therefore, it is necessary to reform the course system of Chinese language and literature major, so as to give full play to practical function of this system, promote students' overall development, and thus provide guarantee to the improvement to teaching quality.

Thought and basic framework of innovation to the course system of Chinese language major in colleges and universities

\section{Basis for determination of training objective for talents in Chinese language and literature major in colleges and universities}

The determination of talent cultivation objective is an important piece of work in innovation to the course system of Chinese language and literature major. It is a primary issue that should be solved by relevant education departments. Simply speaking, the determination of talent cultivation objective is to set up distinctive regulations for the orientation, level, specification and other similar items to be developed for students in this major. At the same time, the objective should also include the talent service orientation and relevant evaluation criteria. Therefore, colleges and universities may adhere to the basic principle of talent cultivation serving regional economic and social development while determining talent cultivation objective. Besides, colleges and universities should also combine the employment orientation of students graduated from the major of Chinese language and literature at present, and determine specific objectives according to specific formulation of school mission: 
cultivate students into talents featured by all-round development of morality, intelligence and physique, with theoretical knowledge, practical ability, relatively high comprehensive quality, creative spirit, and predictability, capable of mastering and applying special knowledge of Chinese language and literature in a systematic way, and with certain spoken language foundation and literature appreciation ability. Moreover, colleges and universities should also guarantee that these talents are competent for secretary in enterprises and public institutions as well as education and academic research in education departments.

Colleges and universities can design relatively scientific and reasonable teaching structure only by accurately mastering the talent cultivation orientation, specification and objective of the present major of Chinese language and literature in working practice. Colleges and universities can provide guarantee to subject orientation of Chinese language and literature major only by adhering to the basic principle of correct professional courses, so as to promote healthy and sound development of course teaching of this major in modern society. At this stage, it can be seen from the employment situation in Chinese society that the employment difficulty of students has already gradually developed as an issue receiving wide social attention. It has adverse effect on social harmony and stability. However, the reason for such difficulty is essentially not talent surplus in Chinese society. On the contrary, it is caused by too modeled education pattern in China's colleges and universities at present. Employment ability of cultivated graduates is disjointed from market requirements, leading enterprises to have no personnel to use. As a result, it is difficult for student employment ${ }^{[1]}$. Therefore, to improve students' employment ability under the present circumstance of national enrollment plan, colleges and universities must reform and make innovation to the course teaching system according to students' employment needs. Colleges and universities must pass this road for survival and development in the new period. That is to say, Chinese language and literature major can obtain the final priority of survival and development only by making reasonable innovation to the course system, so as to cultivate more practical talents for the society, and meet relevant needs for social construction and development.

\section{Make innovation to the basic framework of the course system in Chinese language and literature major}

To adapt to development needs of the present higher education in China, and meet social demands for college talent cultivation and needs for students' development, colleges and universities can use for reference advanced foreign experience in the process of making innovation to the course system of Chinese language and literature major, and construct scientific and reasonable course systems adaptive to specific conditions with student employment as the orientation and improvement to their comprehensive quality as the starting point.

Lay emphasis on the two basic courses: foreign language education and online education

In foreign language course teaching in the major of Chinese language and literature, teachers can take foreign language training and relevant intensive trainings as the fundamental education mode, guarantee that students can use simple foreign language websites, read foreign language textbooks and famous literary works, and use foreign language to look up relevant materials in Sophomore class through centralized training, and provide relevant guarantees to students' interdisciplinary studies of Chinese language. Besides, network information course allows students to master relevant information retrieval techniques in the learning process. Students can be made to look up relevant materials by virtue of network. More importantly, it can also make further improvement to students' computer attainment, and create favorable conditions for their future development. It can be said that foreign language quality and computer quality have important influence on future development of those students majoring in Chinese language and literature under the current situation of gradually intensified tendency of economic integration in the world. Colleges and universities should attach great importance to these two courses, so as to make remarkable improvement to employment competitiveness of those students majoring in Chinese language and literature, and promote their obtainment of better development in the society. 
Organic integration of basic comprehensive quality courses with professional quality courses

To be specific, basic comprehensive quality courses mean comprehensive expansion of the education content with ideological and political education courses as the core, mainly including social mainstream ideological education, contemporary world politics and economy social development situation, issues facing human survival and development, society \& family, and student talents. Students should be allowed to have full understandings of knowledge necessary for jobs in modern society by learning these contents, so as to provide relevant guarantees to their social employment after graduation ${ }^{[2]}$. For professional quality courses, intensification of students' vocational ability is taken as the key teaching content. Education content is selected according to actual needs of the talent market, so as to realize the integration of school education and social work as much as possible. Organic integration of both items can promote overall development of students, improve their position adaptive capacity, and lay a solid foundation for their work and life in the society.

\section{Set up career design courses}

In terms of setup of course system in Chinese language and literature major, career education can be taken as new development orientation. Moreover, we can also positively use for reference America's successful experience in this aspect, and gradually make complete teaching plans. Colleges and universities in various places can add proper career education courses to the original course system, guide students' career design, and organize students to take part in practical training ${ }^{[3]}$. At the same time, colleges and universities can change the original graduation appraisal concept, and cancel graduation theses separated from the employment reality. Instead, colleges and universities can adopt various means (e.g. market survey, employment environment evaluation, and self-assessment) to guide students to apply their knowledge in researching relevant post issues about employment orientation under instructions given by teachers according to students' employment tendency after graduation, so as to realize scientific intensification of students' career direction, allow students to quickly find their positions after employment, improve their social adaptation ability, and promote their sound development.

\section{Make innovation to countermeasures for specialized course system of Chinese language and literature major in colleges and universities}

\section{Establishment of course system}

At first, talent cultivation objective should be determined. Under different social development influence in respective regions, higher education institutions in different regions have different talent cultivation objectives. Therefore, we should summarize formulation of school mission and talent cultivation service purpose of colleges and universities in various places. Basic content of talent cultivation objective in colleges and universities in various places includes the following content: promote students' all-round development of morality, intelligence, physique and aesthetic, intensify students' theoretical knowledge and social practice ability, master relatively systematic knowledge about Chinese language and literature, capable of rationally applying the knowledge in improving their capabilities of language expression, writing, and artistic appreciation, capable of working in educational and secretarial institutions after graduation, basically meet social talent demands, and make relevant contributions to socialist modernization after employment.

Secondly, course teaching objective should be meticulously planned. After the talent cultivation objective is basically determined for the major of Chinese language and literature, the course teaching objective should be planned with the talent cultivation objective as the core. To ensure that teaching of Chinese language and literature can cultivate students in this major into practical talents meeting social demands in the new period, we should take students' language and words application ability, literature creation, analysis and appreciation ability, practical writing skills, and inheritance ability of relevant literature and art theories about Chinese language and literature as key cultivation contents, and properly intensify students' foreign language and application ability as well as networked information retrieval ability ${ }^{[4]}$. On this basis, Chinese language and literature major course objective 
setup divisions in colleges and universities can combine cultivation of students' specific abilities with setup of course teaching objective, analyze specific connotation of ability, take intensification of students' comprehensive ability as an important part of teaching, and lay a solid foundation for enhancement and improvement of the teaching effect.

Thirdly, the content of course teaching should be rationally selected. In terms of selection of course teaching content, we should pay attention to the integration of the most advanced research achievements and the most cutting-edge academic topics with basic teaching content, making students to master basic professional knowledge and understand professional historical development though learning of courses in Chinese language and literature major as well as to open their eyes to the whole world, look to the future, and form clearer cognition for the employment situation of this major and their future development. At the same time, section of course teaching content should also be combined with students' employment skill training, narrow the gap between school education and students' social employment, and pursue for seamless connection between students' graduation and employment to the maximum extent.

Fourthly, classroom teaching methods should be designed in a scientific way. Viewed from the development trend of Chinese language and literature teaching, literature course teaching mainly experienced the development stage lead by work and literary history. In modern society, the trend of integral leadership by literary work and literary history gradually appeared, with important influence on course teaching in the major of Chinese language and literature. Therefore, Chinese teachers in the major of Chinese language and literature in colleges and universities in various places should set up the cognition of integral leadership of literary work and literary history, and meticulously design relevant courses based on such dominant ideas. For instance, Chinese teachers can correctly guide students to read relevant literary works, allow students to master basic rules for occurrence and development of literature through relevant literature background information in the process of reading and understanding literary works, so as to interpret social changes at that time. Ideal effect of Chinese language and literature teaching can be realized only by allowing students to really understand the content to be learned through research and exploration in the process of independent learning.

At last, evaluation mode should be designed in a systematic way. Under the present social situation, to cultivate applied talents, we should take skill-oriented course teaching as the key point. However, skill-oriented course assessment is certainly different from traditional theoretical examination ${ }^{[5]}$. Therefore, colleges and universities in various places should flexibly use various modes of examination in the process of making innovation to the course system, select proper assessment methods (e.g. field questioning, exercises, group analysis, summary homework, and work seminar) according to specific teaching content, so as to complete the assessment content, intensify multi-dimensional and systematic features of examination and evaluation mode in the major of Chinese language and literature, and minimize the assessment with process assessment substituted by one end term examination performance. At the same time, social evaluation system can be selectively introduced according to actual school running conditions, so as to give the authority of assessment and evaluation for some courses to relevant professional social departments, integrate school education with social employment, and provide relevant guarantees to students' future development.

\section{Construction of major direction of Chinese language and literature}

Viewed from relevant surveys and researches in recent years, students graduated from the major of Chinese language and literature are mainly engaged in middle and primary school language teachers and secretaries in enterprises and public institutions, excluding those students applying for postgraduate courses. With intensified international influence of China, Chinese learning gradually becomes very popular in foreign countries. More and more students applied for the major of Chinese for foreigners, and more and more graduates are engaged in journalism. On this basis, in terms of construction of major direction of Chinese language and literature, colleges and universities can offer such directions as relevant education, secretarial, press, and Chinese for foreigners, set up relevant backbone educational courses and application courses for these four directions, and ensure scientificity and systematicness of education for Chinese language and literature major. 


\section{Conclusion}

To sum up, to cultivate students into talents with relevant contributions to Socialist modernization through educational practice at this stage, the major of Chinese language and literature must reform and make innovation to the course system, comprehensively consider relevant factors influencing the teaching quality of Chinese language and literature major at present, reform and make innovation to talent cultivation objective, course teaching objective, teaching content, assessment \& evaluation mode, and other matters, create a good learning atmosphere for students in this major, and lay a solid foundation for students' future development.

\section{References}

[1] Qu Wenjun, Exploration and Practice of Innovation to Course System Construction of Chinese Language and Literature Major, Journal of Linyi Teachers’ College, 2010, 32 (2): 1-4;

[2] Xiang Biao, Employment Tendency of Students Majoring in Chinese Language and Literature and Course System Reform in Local Colleges and Universities, Journal of Chongqing College of Education, 2012, 25 (4): 115-119;

[3] Yu Dan, Construction of Training Course System in Chinese Language and Literature Major, Journal of Mudanjiang Normal University (Philosophy Social Sciences Edition), 2012 (5): 140-141;

[4] Li Haitao, Construction of Featured Course System in Chinese Language and Literature Major in Local Colleges and Universities - With the Reform of Chinese Language and Literature Major in Pingxiang University as an Example, Journal of Pingxiang University, 2015 (2): 100-103;

[5] Li Ling, Exploration and Practice of Creative Course System Construction in Chinese Language and Literature Major, Course Education Research, 2015 (6): 40-40 